\title{
García López, Daniel J. La máquina teo-antropo-legal. La persona en la teoría jurídica franquista. Madrid: Dykinson, 2020.
}

\author{
Inés Fernández Caba \\ Departamento de Derecho Internacional Público y Relaciones Internacionales \\ Universidad de Granada
}

Fecha de recepción 06/05/2020 I De publicación: 28/12/2020

En febrero de 2020 Almudena Grandes publicó la quinta entrega de su serie Episodios de una guerra interminable, una saga galdosiana sobre la guerra y la dictadura franquista, bajo el título La madre de Frankeinstein. En la novela se narran los últimos años de Aurora Rodríguez Carballeira, internada en un psiquiátrico tras el asesinato de su hija. Pero se cuenta más. Nos sitúa ante la construcción de una psiquiatría que trataba de combinar eugenesia, de procedencia nazi, y catolicismo. La figura clave en la novela es Antonio Vallejo Nájera. Justo un mes después, a inicios de marzo de 2020, la editorial Dykinson publicó el libro La máquina teo-antropo-legal, de Daniel J. García López, Profesor en el Departamento de Filosofía del Derecho de la Universidad de Granada. En este libro Antonio Vallejo Nájera también es protagonista, pero comparte escenario con un jurista: José Castán Tobeñas. Ahora bien, ¿qué relación hay entre los libros de Almudena Grandes y de Daniel J. García?

Salvando las distancias intelectuales y de estilo, lo cierto es que leyendo el segundo de los libros se puede entender bien el discurrir del argumento del primero. ¿Por qué la obsesión de Vallejo Nájera que reproduce la propia Aurora Rodríguez en construir un ideal de mujer? Porque esta obsesión ya estaba presente entre los juristas del régimen antes incluso del golpe de Estado. Aquí es donde Daniel J. García López realiza un análisis arqueológico de la categoría persona en el derecho y la psiquiatría, la cual fue desarrollada durante la dictadura por profesionales que construyeron sus posiciones antes de la guerra que acabó con la Segunda República. Tanto José Castán Tobeñas como Antonio Vallejo Nájera, y todo su entorno de discípulos y acólitos, hicieron funcionar lo que el autor plantea como una máquina que separa, por medio de la excepción, lo normal de lo patológico. Se trata de una separación que se coloca entre biopolítica y teología política. Esto es lo que puede explicar la peculiar forma de eugenesia que se practicó durante la dictadura franquista y que se legitimó jurídicamente. 
Esta máquina teo-antropo-legal construye un ideal de persona, ya que se trata de "un mecanismo que produce imágenes de hombres, que establece modelos antropológicos, que plantea una antropogénesis" (p. 30). A partir del espacio vacío que produce esta máquina, la vida queda capturada: dentro y fuera del ordenamiento jurídico. En el último capítulo del libro, Al margen del ser, se nos plantea qué ocurre con quienes son situados fuera de la norma sobre la vida: homosexuales, lesbianas, mujeres que ejercen el trabajo sexual, personas que viven en la calle o que hablan otras lenguas. Sobre estas se ejercerá todo un aparato disciplinario con el objetivo de salvaguardar, en el sentido teológico del término, la noción normativa de persona.

Esta noción de persona viene relatada en los capítulos III El ser jurídico y IV El ser psiquiátrico. Allí se articulan los engranajes de la máquina en su doble vertiente. Tanto el derecho civil como la psiquiatría coincidieron en la construcción de un ideal de persona durante la dictadura: el hombre íntegrototal, católico y situado en la hispanidad. Esta concepción jurídico-psiquiátrica atravesada por la teología se explica por la idea de Nuevo Estado que nos relata el autor en el segundo capítulo (El cuerpo de la dictadura) a partir del estudio de los discursos del dictador, Francisco Franco, y de su realización jurídica. La dictadura franquista necesitaba para su supervivencia de un tipo concreto de persona y esta no podía conseguirse sólo con un poder represivo. Esta quizás sea la virtud del libro de Daniel J. García López: no centrarse en los grandes entramados represivos de la dictadura, sino acudir a los discursos microfísicos que disciplinaban y normalizaban. Es por ello que no se atienda al derecho penal, sino al civil, aquel que regula las relaciones entre los individuos. Lo que supone una novedad a la hora de acercarse a este tema.

Esta manera foucaultiana de proceder, habitual en los anteriores libros del autor, nos sitúa ante un reto: la construcción de una nueva subdisciplina dentro de la filosofía jurídica que Daniel J. García López denomina teo-antropología jurídica. Es una propuesta interesante, aunque puede que haya quienes crean que aquí el libro apunta demasiado alto. Sin embargo, esperemos que no le ocurra como a Ícaro y el sol derrita la cera que mantiene unida sus alas, cayendo desplomado en el laberinto que la pintora Eva Rodríguez Góngora ha planteado como portada del libro.

Finalmente, me gustaría resaltar que nos encontramos ante un pequeño dispositivo que nos ayudará con la lectura de la espléndida novela de Almudena Grande y, más aún, con la comprensión de nuestro pasado más reciente. Lo que, en definitiva, nos plantea es poner en cuestión los aprendizajes dados por sentados, pues muchos de los personajes que aparecen en el libro de Daniel J. García López siguen siendo estudiados a día de hoy en las Facultades de Derecho como doctrina hegemónica. 